Түйін сөздер: азық-түлік қауіпсіздігі, мемлекеттік реттеу, мемлекеттік реттеудің рөлі, тамақ қауіпсіздігін реттеу.

\title{
ОБ АВТОРАX
}

Нұрғазы Шыңғыс Әскербекұлы - докторант Ph.D., Университет Нархоз, Алматы, Республика Казахстан, e-mail: shynggys.nurgazy@narxoz.kz*

Сейтказиева Аружан Мукатаевна - доктор экономических наук, профессор, Университет Нархоз, Алматы, Республика Казахстан, e-mail: aruzhan.seitkazieva@narxoz.kz

Симанавичене Жанетта - доктор экономических наук, профессор, Университет Миколаса Рёмериса, Вильнюс, Литва, e-mail: zasiman@mruni.eu

МРНТИ 06.71.03.

JEL Classification: $\mathbf{H 7 5}$

https://doi.org/10.52821/2224-5561-2021-3-77-89

\section{ҚАЗАҚСТАН РЕСПУБЛИКАСЫНЫН МЕМЛЕКЕТТІК САТЫП АЛУ НАРЫҒЫНЫҢ ТИІМДІЛІГІН АРТТЫРУ ЖОЛДАРЫ}

\author{
Р. Қ. Елшібаев ${ }^{1 *}$, С. А. Кожабаева ${ }^{2}$, Б. Т. Бейсенгалиев ${ }^{2}$ \\ ${ }^{1}$ Нархоз Университеті, Алматы, Қазақстан Республикасы \\ ${ }^{2}$ Қазақ экономика, қаржы және халықаралық сауда университеті, \\ Нұр-Сұлтан, Қазақстан Республикасы
}

\begin{abstract}
АНДАТПА
Зерттеу мақсаты - Қазақстан Республикасында мемлекеттік сатып алу жүйесінің тиімділігін жоғарылату бойынша теориялық-әдістемелік әзірлемелер мен экономикалық негізделген ұсыныстар әзірлеу.

Зерттеу әдіснамасы. Зерттеу жүргізу барысында жалпы ғылыми танымның әртүрлі әдістері, салыстырмалы талдау, экономика-статистикалық талдау әдістері қолданылды.

Зерттеудің бірегейлігі/ құндылызы. Зерттеу нәтижелері әлеуметтік-экономикалық дамудың өңірлік мақсатты бағдарламаларын әзірлеу, мемлекеттік сатып алу қызметін реттейтін заңнамалық және нормативтік актілерге өзгерістер мен толықтырулар енгізу кезінде қолданылуы мүмкін.

Зерттеу нәтижелері. Зерттеу жүргізу әдістерін қолдану арқылы мемлекеттік сатып алу нарығының концептуалдық негіздері ашылды, Қазақстан Республикасында мемлекеттік сатып алу жүйесінің эволюциясы көрсетілді, қазақстандық және шетелдік тәжірибелерге салыстырмалы талдау жасалды, мемлекеттік сатып алу нарығының негізгі проблемалары айқындалды және оның тиімділігін жоғарылату бойынша экономикалық негізделген ұсыныстар мен теориялық-әдістемелік ережелер әзірленді.

Түйін сөздер: мемлекеттік сатып алу, сатып алу қызметі, тендер, конкурстық өтініш, аукцион, мемлекеттік тапсырыс беруші, әлеуетті жеткізуші.
\end{abstract}

\section{KIPICПЕ}

Қазіргі динамикалық даму және жедел өзгерістер жағдайында ұлттық шаруашылық жүйесін мемлекеттік реттеу стратегиясы мен тактикасына жаңа талаптар қойып отыр. Мұндай жағдайда мемлекеттік функцияларды іске асыру құралдарын, соның ішінде мемлекеттік сатып алу жүйесінің механизмдерін 
сапалық тұрғыдан өзгерту қажеттілігі туындайды. Ол ұлттық ресурсты басқаруды республикалық және жергілікті деңгейлерде қамтамасыз ететін қоғамдық реттеудің ажырамас элементі болып табылады.

Қазір мемлекеттік сатып алу платформасы базасында 25000 нан астам мемлекеттік ұйымдар (тапсырыс берушілер) мен 220000 нан астам потенциалды жеткізушілер өзара әрекеттестікте қызметін жүзеге асырады. Сондықтан ұлттық экономикада бұл сегменттің рөлін бағалау қиынға соғады.

Мемлекеттік сатып алулар бюджеттік жоспарлаумен қатар ел экономикасын басқарудың нақты құралы болып табылады. Осыған байланысты мемлекеттік тапсырыс жүйесінің тиімділігін жоғарылату жолдарын зерттеу ерекше маңызды міндеттер санатына жатқызылуы тиіс. Себебі, мемлекет алдында алдында тұрған басымдықты міндеттерді шешу мен экономиканың қызмет етуінің ұтымды параметрлеріне жету үшін бюджет қаражаттарын жұмсауды дұрыс ұйымдастыру мен тиімді пайдалану қажет.

Қазіргі таңда ақпараттық және коммуникациялық технологияларды интенсивті пайдалану мемлекеттік тапсырыс жүйесі үрдісінің транспаренттілігін қамтамасыз ету мен ашықтығын жоғарылату жолымен көптеген кемшіліктерді жоюға мүмкіндік береді. Мемлекеттік сатып алу порталында тапсырыс берушілердің тауарларды жеткізуге, жұмыстарды орындауға, қызметтер көрсетуге қажеттіліктері туралы мәліметтерді жинау мен жариялау, сондай-ақ жариялы түрде атқару ұйымдастырылады. Барлық деңгейлер мен сатыларда бұл механизмнің мөлдірлігі мемлекеттік тапсырыс көлеміндегі болуы ықтимал мәжбүрлі өзгерістердің алдын алуға мүмкіндік береді. Ол өз кезегінде отандық тауар өндірушілерді ынталандыру және экономиканың салалық құрылымын реттеу арқылы елдегі жиынтық сұраныстың өсіміне әсер етеді. Сондықтан бүгінгі күні Қазақстанда мемлекеттік қажеттілік үшін өнімдерді (жұмыстар, қызметтер) сатып алу бойынша ашық әрі дұрыс жолға қойылған электрондық сауданы іске асыру өте өзекті мәселе болып табылады.

Коронадағдарыс кезеңінде республикалық және жергілікті бюджеттің шығыстарын оңтайландыру, мемлекеттік сатып алуды басқару жүйесін жетілдіру қажет екендігі сөзсіз. Қазіргі жағдайда мемлекеттік тапсырыс Республика бюджетінің шығыс бөлігінің айтарлықтай үлесін алады. Өйткені ұзақ мерзімді кезеңде ұлттық экономика мен оның өнеркәсіптік секторының тұрақты дамуы үшін негізгі фактор болып табылады. Сол себепті бюджет қаражаттарын тиімді пайдалану және қатысушылар үшін мүмкіндіктерді кеңейту бойынша мемлекеттік тапсырысты басқару жүйесін жетілдіру айрықша маңызға ие болады.

Бәсекелік ортада мемлекеттік сатып алу нарығының қалыптасу және даму проблемалары бірқатар отандық және шетелдік ғалымдардың еңбектерінде қарастырылған. Мемлекеттік сатып алуды ұйымдастыру мен басқару тиімділігін жоғарылату, мемлекеттік сатып алу мехаизмдерін дамыту мәселелері М. Махмутованың, Ф. А. Гаджиевтің, А. А. Ниязовтың, Э. Д. Жунусованың және басқа да ғалымдардың еңбектерінде көрініс тапқан [1-4]. Зерттеу тақырыбы бойынша еңбектерде экономикалық қатынастар жүйесінде мемлекеттік тапсырысты жоспарлау, ұйымдастыру және іске асыру ерекшеліктерін түсіну үшін қажетті ғылыми пікірлер қарастырылған. Алайда мемлекеттік тапсырыс жүйесіне арналған теориялық-әдістемелік әзірлемелердің жеткіліксіздігі байқалады. Әсіресе, мемлекеттік сатып алу нарығының концептуалдық негіздерін нақтылау, реттеу механизмдері мен инстиуционалдық негіздерін құру бойынша зерттеулер қажеттілігі байқалады.

\section{НЕГІЗГІ БӨЛІМ}

Қазақстан Республикасының мемлекеттік сатып алу туралы заңына сәйкес, мемлекеттік сатып алу деп тапсырыс берушілердің тауарларды, жұмыстарды, көрсетілетін қызметтерді толықтай немесе ішінара бюджет қаражаты есебінен немесе меншікті қаражаты есебінен сатып алуды айтамыз [5].

Мемлекеттік сатып алуды жүзеге асырудың мақсаты мемлекеттік инфрақұрылымды материалдыққаржылық тұрғыдан тиімді түрде қамтамасыз ету. Ол мынадай 2 бөліктен тұрады:

- экономикалық: көлік, коммуналдық қызметтер, мемлекеттік институттардың ағымдағы экономикалық қызметін жүзеге асыру үшін қажетті алғашқы инфрақұрылымдар;

- әлеуметтік инфрақұрылым: мектептер, ауруханалар, емханалар, балабақшалар немесе басқаша айтқанда қоғамның ағымдағы қызметі үшін қажетті инфрақұрылымдар [6]. 
Мемлекеттік сатып алуды жүзеге асыру кезінде мынадай қағидаттар сақталуы керек:

- мемлекеттік сатып алу үшін пайдаланылатын ақшаны оңтайлы және тиімді жұмсау; беру;

- әлеуетті өнім берушілерге мемлекеттік сатып алуды өткізу рәсіміне қатысу үшін тең мүмкіндіктер

- ашықтық пен айқындықты қамтамасыз ету;

- мемлекеттік сатып алуға қатысушылардың жауапкершілігі;

- сыбайлас жемқорлыққа жол бермеу;

- зияткерлік меншік объектілеріне құқықтарды сақтау [5, 4 б.].

Мемлекеттік сатып алу процесі келесідей 3 кезеңнен тұрады:

1) мемлекеттік сатып алудың жылдық жоспарын дайындау мен бекіту;

2) өнім берушіні таңдау және онымен мемлекеттік сатып алу туралы шарт жасасу;

3) мемлекеттік сатып алу туралы шартты орындау.

Қазіргі кезде мемлекеттік сатып алу аясындағы үлкен мәселелердің бірі осы кезеңдерді ұйымдастыру мен іске асыру процесін оңтайландыру болып табылады. Себебі, ол өз кезегінде бюджет қаражатын жоспарлау мен пайдалану жағдайына да өзінің ықпалын тигізеді. Сондықтан мемлекет тарапынан бұл бағытта жүйелі түрде жұмыстар жүргізіліп отырылуы тиіс.

Қазақстан Республикасында мемлекеттік сатып алу нарығының қалыптасуы мен дамуының негізгі кезеңдерін мынадай сурет түрінде көрсетуге болады (Сурет 1).

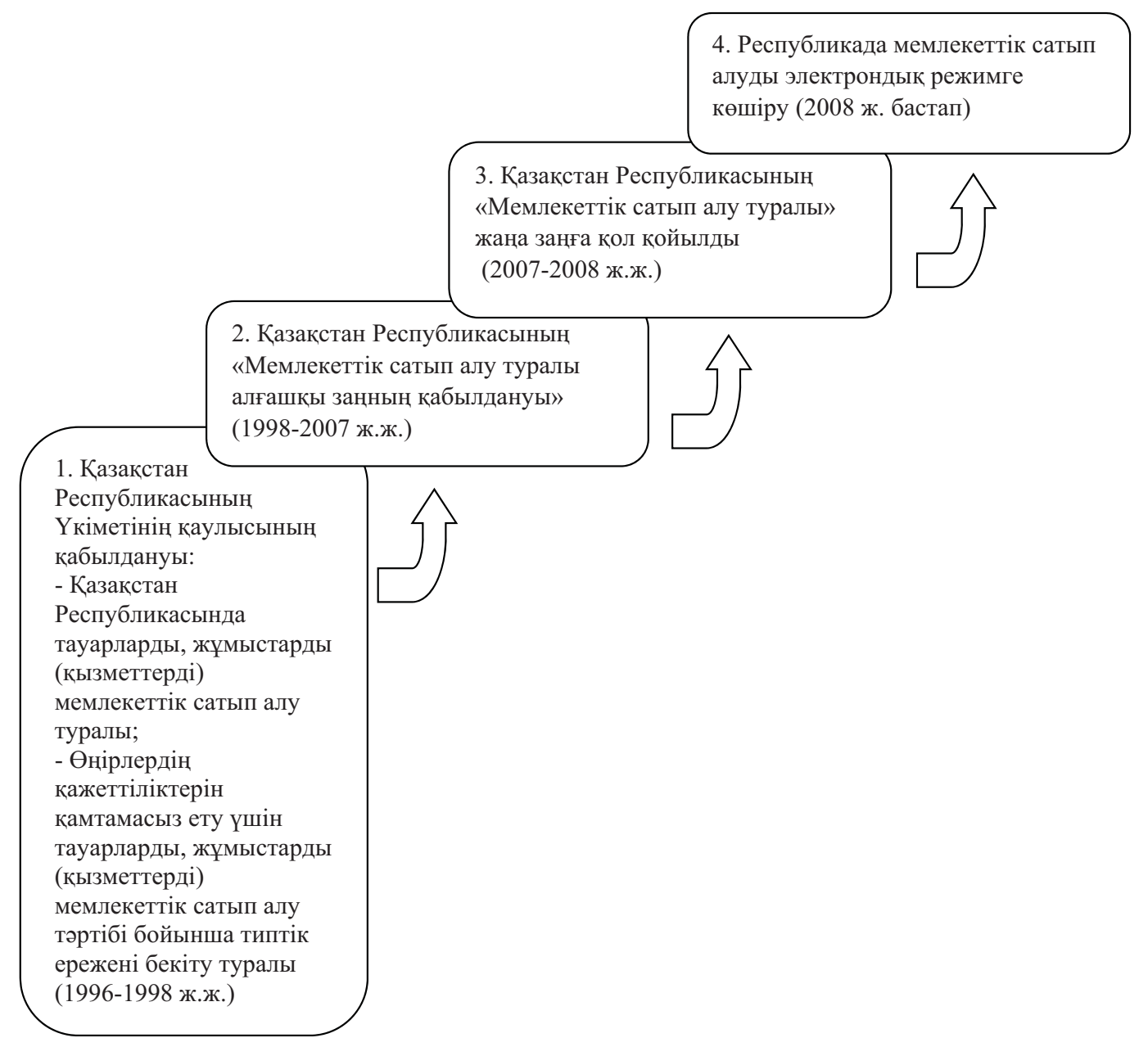

Сурет 1 - Қазақстан Республикасында мемлекеттік сатып

алу нарығының қалыптасу және даму кезеңдері

Ескерту - [1] дереккөз негізінде авторлармен құрастырылған 
Бірінші суреттен көріп отырғанымыздай тәуелсіздік алғаннан кейін ұлттық экономиканың қалыптасуының алғашқы кезеңінде мемлекеттік сатып алу мәселесі қолға алынып Үкімет қаулылары мен арнайы заңдар қабылданды. Қазіргі кезде елімізде мемлекеттік сатып алу 2005 жылы 4 желтоқсанда қабылданған Қазақстан Республикасының мемлекеттік сатып алу туралы № 434 - V заңы негізінде әрекет етеді. Осы заң бойынша мемлекеттік сатып алудың бірнеше тәсілдері көрсетілген.

Жүзеге асыру тәсіліне байланысты тендерлер ашық және жабық болуы мүмкін. Оны келесі сурет (Сурет 2) түрінде көрсетуге болады.

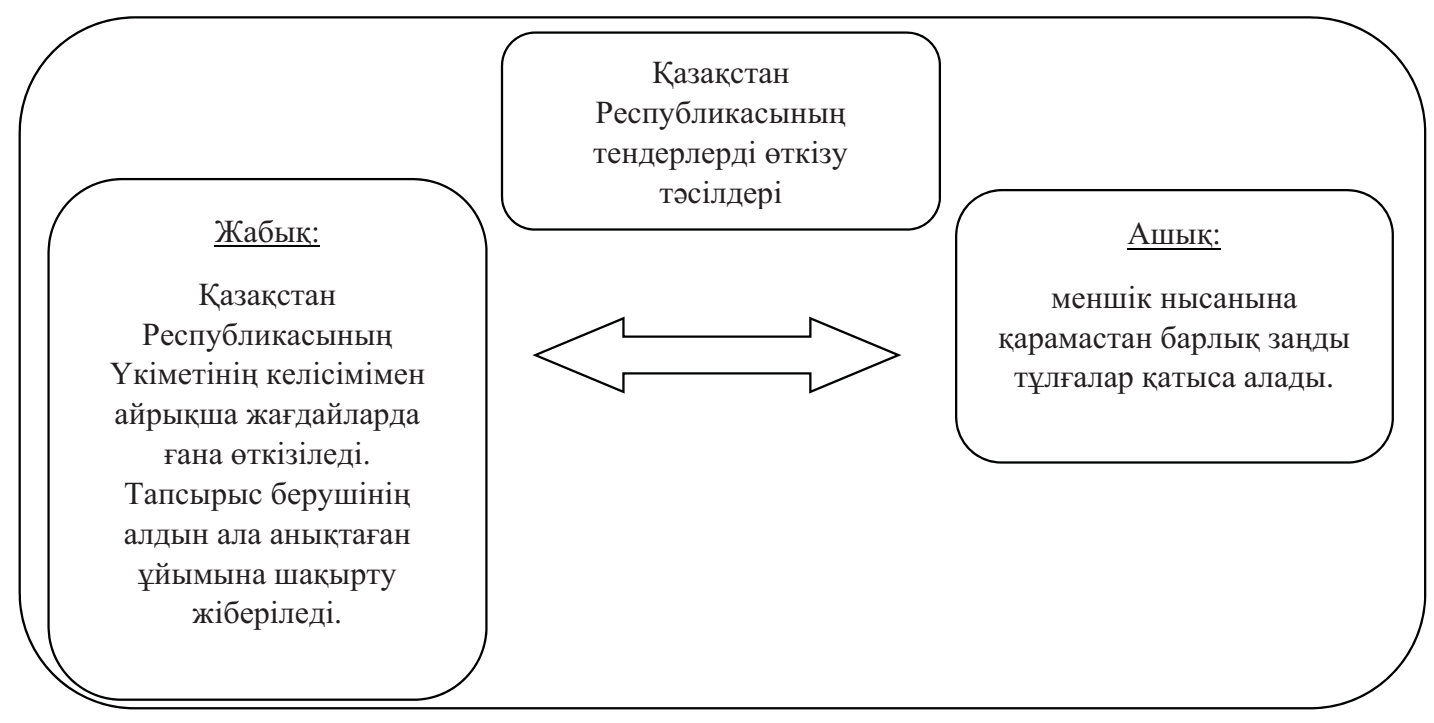

Сурет 2 - Мемлекеттік сатып алуды ұйымдастыру формалары Ескерту - [5] дереккөз негізінде авторлармен құрастырылған

Қазақстан Республикасының заңнамасына сәйкес мемлекеттік құпия болып табылатын еліміздің қауіпсіздігі мен қорғаныс қажеттіліктеріне арналған тауарларды (жұмыстарды, қызметтерді) жеткізу бойынша жабық тендер өткізіледі.

Ашық тендерлер келесі тәсілдердің бірін таңдау арқылы өткізіледі:

- конкурс (ашық конкурс, біліктілікті алдын ала іріктеумен жүргізілетін конкурс, екі кезеңдік рәсімдер пайдаланылатын конкурс);

- баға ұсыныстарын сұрату;

- бір көзден алу;

- аукцион;

- тауар биржалары.

Қазақстан Республикасының Мемлекеттік сатып алу туралы заңына енгізілген өзгерістер мен толықтыруларға сәйкес бюджет қаражаттарының жұмсалуына мониторинг жасау, аудит және бақылау, сондай-ақ мемлекеттік тапсырысты орналастыру бойынша заңнаманың сақталуын Қазақстан Республикасының қаржы министрлігінің мемлекеттік сатып алу және қаржылық бақылау Комитеті жүзеге асырады. Ал жергілікті деңгейлерде уәкілетті органның территориялық басқармасы және әкімшілік-территориялық бірліктің жергілікті өзін-өзі басқару органы қадағалайды.

Елімізде мемлекеттік сатып алу жүйесін жетілдірудің маңызды бір бағыты осы қадағалаушы органдардың қызметін ұтымды үйлестіру мен ашықтығын қамтамасыз ету болып табылады. Сондықтан да әрбір бақылаушы органның өкілеттілігі мен құзетін, жауапкершілігін айын ажыра білген дұрыс. Сол себепті мемлекеттік сатып алу аясындағы бақылаушы органдардың заманауи жүйесін төмендегі суреттен (Сурет 3) көруге болады. 


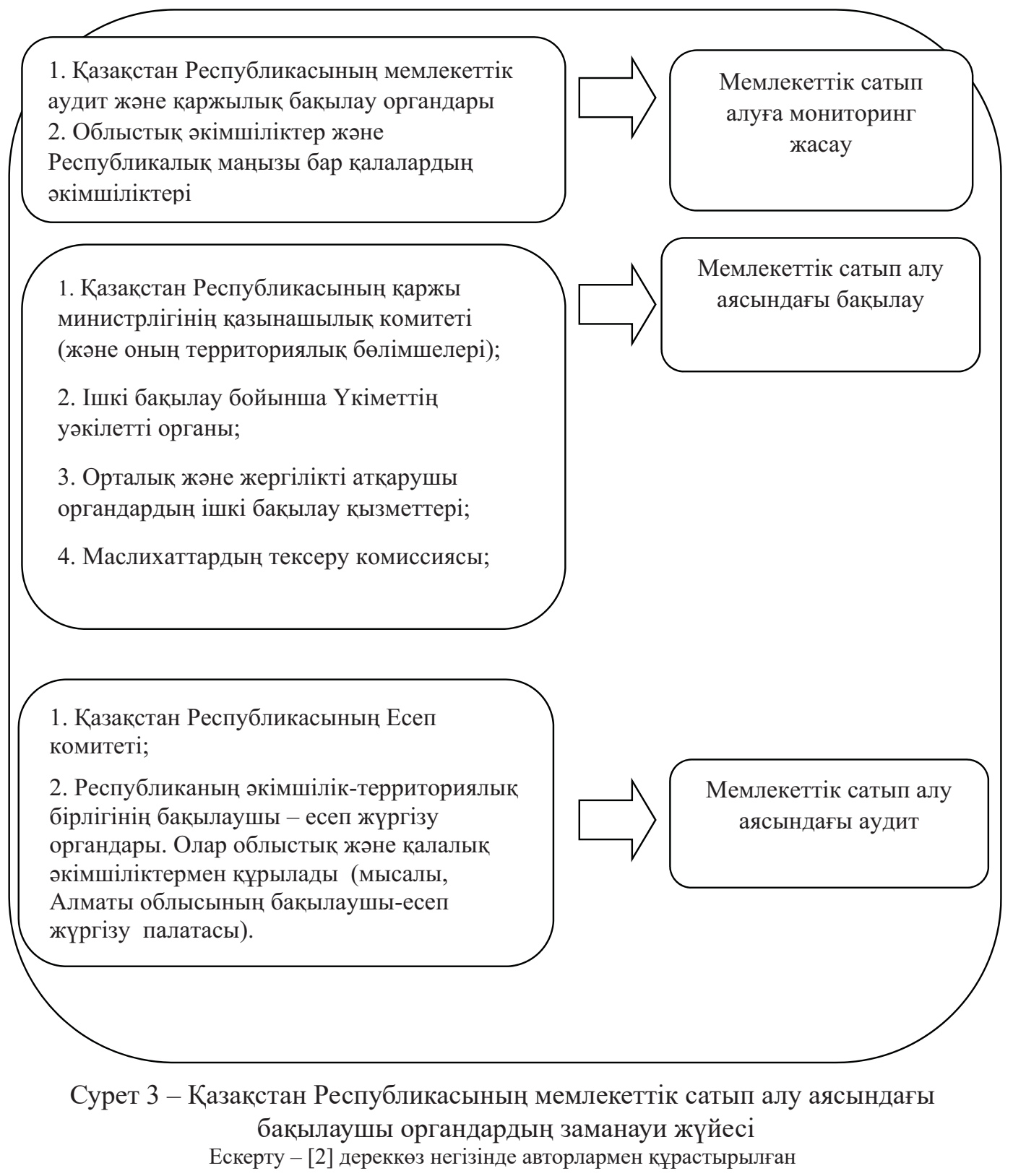

Мемлекеттік сатып алу аясындағы сапаны қамтамасыз ету үшін әлеуетті жеткізушілерге (өнім берушілерге) бірқатар біліктілік талаптары қойылады. Олар:

- құқық қабілеттілігінің (заңды тұлғалар үшін), азаматтық әрекетке қабілеттілігінің (жеке тұлғалар үшін) болуы;

- қаржылық орнықты болуы және тиісті есеп жылына 6 еселенген айлық есептік көрсеткіштен асатын берешегінің болмауы;

- банкроттық не таратылу рәсіміне жатқызылмауы;

- бекітілген келісім шартты орындау үшін жеткілікті материалдық, еңбек және қаржы ресурстарының болуы;

- жұмыс тәжірибесінің болуы.

Біліктілік талаптарының сақталуы және жоғары деңгейде болуы мемлекеттік сатып алу аясындағы тәуекелдерді азайтуға және тиімділікті жоғарылатуға, бюджет қаражаттарының ұтымды пайдаланылуына өзіндік әсерін тигізеді. 
Мемлекеттік сатып алу процесінің тиімділігін бағалау үшін бюджет қаражаттары шығыстарын қысқартудың абсолютті және салыстырмалы көрсеткіштерін есептеуге болады. Ол мынадай формулалар арқылы есептеледі:

Абсолютті қысқарту теңге өлшем бірлігімен есептеледі:

$$
\mathrm{Ca}=\mathrm{Cn}-\mathrm{Ck}-3
$$

Мұндағы, $C n$ - келісім шарттың бастапқы бағасы;

Ск - жасалған келісім шарттың құны;

3 - тапсырыс берушінің конкурсты өткізуге жұмсаған шығындары.

Салыстырмалы қысқарту \% түрінде келесі формуламен есептеледі:

$$
\mathrm{Co}=\mathrm{Ca} / \mathrm{Cn} \times 100 \%
$$

Есепті кезеңде тауарларды жеткізуге тапсырысты орналастыру кезінде бюджет қаражаттарының шығындарын қысқарту әрбір тендер бойынша бюджет қаражаттарының шығыстарын қысқарту соммасы ретінде есептеледі [7].

Салыстырмалы тиімділік көрсеткіші. Мұнда тендерлерді өткізу 3 нұсқа бойынша анықталады. Конкурста сатылып алынған тауарлардың бағасын жеткізу шарты бойынша мынадай бағалармен салыстыру негізінде жүргізіледі:

- жеткізушімен ұсынылған тауардың орташа нарықтық бағасымен;

- тауардың орташа нарықтық бағасымен;

- тауардың алдыңғы конкурстағы келісім шарттық бағасымен [8].

Біздің ойымызша, мемлекеттік тапсырыс үшін өндірілетін тауарлар (жұмыстар, қызметтер) сапасы, мемлекеттік тапсырысты орналастыру кезінді теріс пиғылды әрекеттер мен бұзушылықтардың орын алмауы басты назарда болуы тиіс.

Аймақтық деңгейде мемлекеттік тапсырысты орналастырудың тиімділігі келесідей көрсеткіштермен анықталады:

- мемлекеттік қажеттілік үшін сатып алу көлемінің динамикасы;

- сатып алу саны мен орналастыру тәсілі бойынша мемлекеттік тапсырысты орналастырудың құрылымы;

- сатып алу саны мен орналастыру соммасына байланысты өнім берушілер топтары бойынша мемлекеттік тапсырысты орналастырудың құрылымы;

- орналастыру тәсілі бойынша мемлекеттік тапсырыстың көлемі мен динамикасының құрылымы;

- мемлекеттік тапсырысты орындамау немесе белгіленген талапқа сай емес орындау тәуекелі [9].

Елімізде мемлекеттік сатып алу нарығындағы жағдайды талдау әдейі немесе кездейсоқ сипатта жасалатын бұрмалаушылықтардың жыл сайынғы өсімін көрсетіп отыр. Нақты айтқанда мемлекеттік бюджеттен осы мақсатта бөлінетін қаржы көлеміне пропорционалды түрде артып отырғаны байқалады.

Қазақстанда мемлекеттік тапсырысты өткізу тиімділігін төмендететін негізгі факторларға келесілерді жатқызуға болады:

- тапсырыс беруішінің өтінім дайындайтын өкілінің біліктілігі мен мотивациясының төмендігі;

- тиімсіз жоспарлау;

- тендерлік құжаттарды тексерудегі қателіктер;

- жеткізушіні (өнім берушіні) адекватты тексерудің және оның жұмысы туралы кері байланыстың жоқтығы;

- жеткізушіні (өнім берушіні) таңдау мен ұсыныстарды бағалаудағы қателіктер;

- ұйымдастырудағы кемшіліктер мен техникалық проблемалар.

Осы аталған өзекті мәселелер елімізде мемлекеттік сатып алу жүйесін әрі қарай жетілдіру қажеттігін көрсетеді. Тауарларды (жұмыстарды, қызметтерді) жеткізудің түсінікті және қол жетімді жүйесін жа- 
сау мен өткізу тәртібін оңтайландыру қажет. Осы мақсатта мемлекеттік сатып алу жүйесінің шетелдік озық тәжірибелері зерттелді. Әрине озық үлгілерді отандық нарықтың ерекшелігін ескере отырып бейімдеу жолдарын қарастыру керек.

Мемлекеттік сатып алуды ұйымдастырудың шетелдік тәжірибесі халықаралық қаржылық институттардың (ХҚИ) дайындаған әдістемелік ұсыныстарына негізделеді. Мемлекеттік сатып алудың шетелдік үлгілерін 4-суреттен көруге болады.

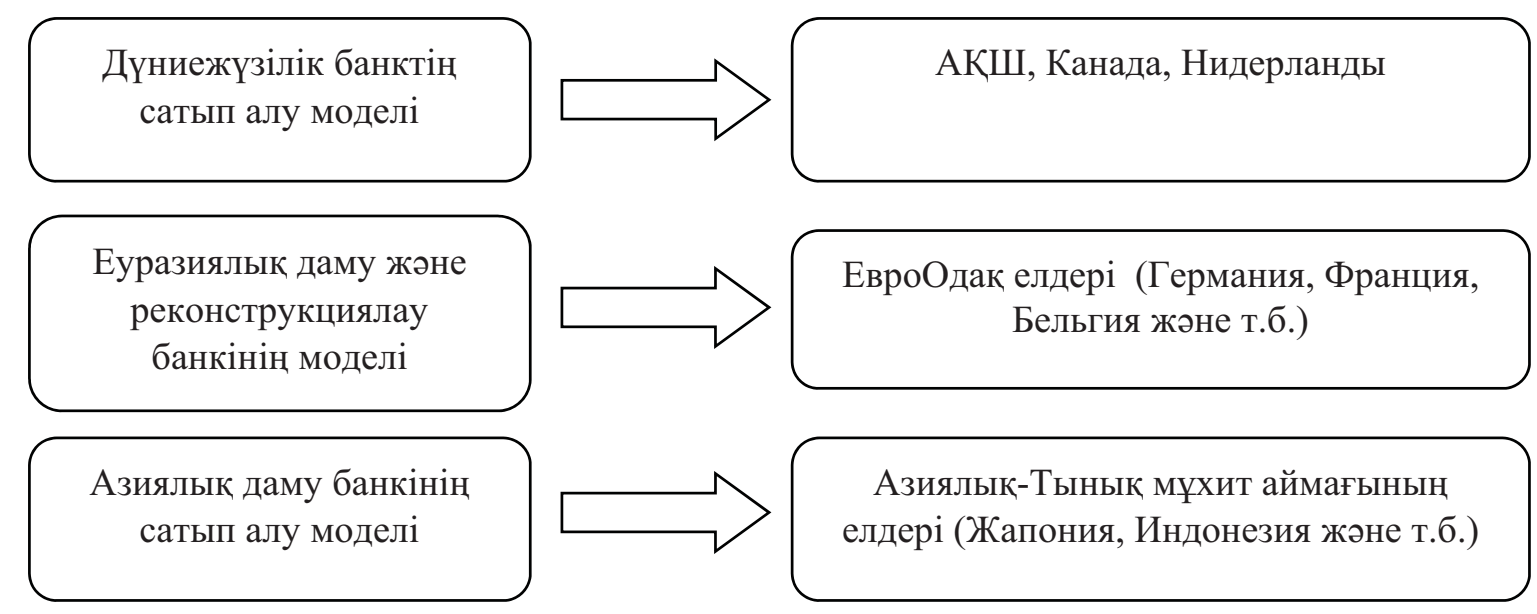

Сурет 4 - Мемлекеттік сатып алудың негізгі модельдері

Ескерту - [10] дереккөз негізінде авторлармен құрастырылған

Әрбір модельдердің айырмашылықтарына қарамастан олар бір ортақ идеяны көздейді. Яғни, мемлекеттік сектор желісі бойынша сатып алу процесінің ашықтығы мен жариялылығы, тендерлерді өткізу тәсілдері мен кезеңдерінің барлығы ашық түрде болуы, сондай-ақ әрбір қатысушының ғаламтор желісі арқылы танысу мүмкіндігінің болуы басты талап болып табылады.

Қазір Қазақстан Республикасының Дүниежүзілік банкпен (ДБ), Еуразиялық даму және реконструкциялау банкімен (ЕДРБ), Азиялық даму банкімен (АДБ) тығыз әріптестік байланыстар орнатылған. Ал ең ірі мемлекеттік тапсырыс беруші Самұрық-Қазына әл ауқат қоры екендігі белгілі. Сондықтан отандық және шетелдік модельдердің салыстырмалы кестесін (Кесте 1) жасау мақсатқа сай болады.

Кесте 1 - ХҚИ сатып алу регламентін талдау

\begin{tabular}{|c|c|c|c|c|}
\hline Сатып алу ережесі & $\begin{array}{c}\text { Дүниежүзілік банктің } \\
\text { моделі }\end{array}$ & ЕДРБ моделі & АДБ моделі & $\begin{array}{c}\text { Самұрық - Қазына } \\
\text { әл-ауқат қоры }\end{array}$ \\
\hline Жоспарлау & $\begin{array}{l}18 \text { айға сатып алу жоспа- } \\
\text { ры }\end{array}$ & $\begin{array}{l}\text { Жобаны іске асыру } \\
\text { мерзіміне сатып алу } \\
\text { жоспары }\end{array}$ & $\begin{array}{l}\text { Бәсекелік сатып алудың } \\
\text { жылдық жоспары } \\
\text { (бірыңғай көзден емес) }\end{array}$ & $\begin{array}{l}\text { Сатып алудың } \\
\text { жылдық жоспары } \\
\text { және ұзақ мерзімді } \\
\text { сатып алу жоспары }\end{array}$ \\
\hline Жеткізушіні таңдау & $\begin{array}{l}\text { Конкурс, сауда. Ірі } \\
\text { және күрделі сатып алу } \\
\text { бойынша алдын ала } \\
\text { біліктілік талаптары } \\
\end{array}$ & $\begin{array}{l}\text { Конкурс, алдын ала } \\
\text { біліктілік талаптары }\end{array}$ & $\begin{array}{l}\text { Бәсекелік негізде таңдау. } \\
\text { Алдын ала біліктілік } \\
\text { талаптарына рұқсат } \\
\text { беріледі. }\end{array}$ & $\begin{array}{l}\text { Тендер, баға } \\
\text { ұсыныстарын сұрату, } \\
\text { тауар биржалары, бір } \\
\text { көзден сатып алу. }\end{array}$ \\
\hline $\begin{array}{l}\text { Ұйымдастыру- } \\
\text { шылық техникалық } \\
\text { тәртіпті қолдау }\end{array}$ & $\begin{array}{l}\text { Қарыз алушы банктің } \\
\text { келісімі бойынша } \\
\text { жеңілдіктер қолдануы } \\
\text { мүмкін. } \\
\end{array}$ & $\begin{array}{l}\text { Жергілікті жеткі- } \\
\text { зушілерге қатысты } \\
\text { жеңілдіктер } \\
\text { қолданылмайды. } \\
\end{array}$ & $\begin{array}{l}\text { Жергілікті жеткізушілер- } \\
\text { ге қатысты жеңілдіктер } \\
\text { қолданылмайды. }\end{array}$ & Қарастырылған \\
\hline $\begin{array}{l}\text { Баға бойынша } \\
\text { шартты шегерімдер }\end{array}$ & Қарастырылмаған & $\begin{array}{l}\text { Коммерциялық } \\
\text { емес ұйымдар үшін } \\
\text { қарастырылған. }\end{array}$ & Қарастырылмаған & 23 \% дейін \\
\hline
\end{tabular}


Қарастырылып отырған модельдер бойынша мынадай тұжырымдар жасауға болады:

- ХҚИ сатып алу тәжірибесінде әлеуетті жеткізушілерді алдын ала біліктілік талаптары бойынша іріктеу қолданылады;

- сатып алулардың көп бөлігі бәсекелік тәсілдер (конкурс, аукцион, сауда) арқылы жүзеге асырылады;

- баға бойынша шартты шегерімдер, сондай-ақ отандық жеткізушілерге қатысты жеңілдіктер қолданылмайды.

Қарастырылған модельдер дамуындағы ортақ мәселе тендер бойынша сатып алу тауарларды, жұмыстар мен қызметтерді сатып алуға жұмсалатын шығындарды азайтуға мүмкіндік береді, қаражатты жұмсаудың тиімділігін қамтамасыз етеді және мемлекеттік қаражаттар есебінен тапсырыстарды орналастыру кезінде жемқорлық деңгейін төмендетеді.

Алайда Қазақстан Республикасында мемлекеттік сатып алу жүйесінің өзіндік ерекшеліктері бар:

1) сатып алулар Қазақстандағы мемлекеттік сатып алулар туралы барлық ақпаратты біріктіретін бірыңғай веб-порталда іске асырылады [11];

2) республикалық бюджеттің шығыстар құрылымында мемлекеттік тапсырыстың өсуі. Мұны 2-кестеден көруге болады [12].

Кесте 2 - Қазақстан Республикасының 2016-2019 жылдар аралығындағы мемлекеттік сатып алу динамикасы (млрд. тг.)

\begin{tabular}{|c|c|c|c|c|c|}
\hline Жылдар & $\begin{array}{c}\text { Республикалық } \\
\text { бюджеттің шығыстары }\end{array}$ & ЖІӨ & $\begin{array}{c}\text { Мемлекеттік сатып } \\
\text { алу }\end{array}$ & $\begin{array}{c}\text { Мемлекеттік сатып } \\
\text { алу көлемінің бюджет } \\
\text { шығыстарындағы үлесі, } \\
\%\end{array}$ & $\begin{array}{c}\text { Мемлекеттік } \\
\text { сатып алу } \\
\text { көлемінің ЖІӨ \% }\end{array}$ \\
\hline 2016 & 4562,5 & 27172 & 2445,5 & 53,6 & 9,0 \\
\hline 2017 & 8618,6 & 46971 & 3757,7 & 43,6 & 8,0 \\
\hline 2018 & 13289,8 & 53401 & 5874,1 & 44,2 & 11,0 \\
\hline 2019 & 13440,1 & 59614 & 6357,2 & 47,3 & 10,7 \\
\hline Ескерту - [12] дереккөз негізінде авторлармен құрастырылған \\
\hline
\end{tabular}

2-кестеде берілген мәліметтерден көріп отырғанымыздай, 2016 жылы мемлекеттік тапсырыстарды қаржыландыру республикалық бюджеттің шығыстарының жалпы көлемінің 53,6 \% және жалпы ішкі өнімнің 9 \% құраған. 2017 жылы сәйкесінше 43,6 \% және 8 \%, 2018 жылы 44,2 \% және 11 \%, 2018 жылы 47,3\% және 10,7 \% құраған. Яғни, 4 жыл ішінде республикалық бюджет шығыстарындағы үлесі 6,3 \%-ға төмендесе, ЖІӨ үлесі 1,7 \%-ға артқан. Дегенмен 4 жыл ішінде динамика байқалып отыр.

Тауарларды, жұмыстар мен қызметтерді мемлекеттік сатып алудың үлесі республикалық бюджеттің шығыс бөлігінің 50 \% жеткен кезде мемлекеттік сатып алудың толыққанды келісімшарттық жүйесі мен сәйкес институттарды қалыптастыру міндеті стратегиялық маңызға ие болады [13].

3) келесідей тәсілдермен келісім шарт жасасу кезінде мемлекеттік тапсырыстар едәуір тиімді болады:

- баға ұсыныстарын сұрату;

- ашық конкурс;

- ашық аукцион.

Мұны 3-кестедегі мәліметтерден көре аламыз. 2019 жылы бағаларды сұрату әдісі бойынша келісім шарттардың 3,63 \% бұзылса, 71,33 \% орындалған, 25,02 \% орындалу сатысында. Ашық аукцион бойынша 4,32 \% бұзылса, 57,15 \% орындалған, 38,54 \% орындалу барысында, ашық конкурс өткізу кезінде келісім шарттың 4,72 \% бұзылса, 62,23 \% орындалған, 33,05 \% орындалу сатысында. Ал келісім шарттардың ең көбі 9,12 \% тауар биржасындағы саудада бұзылса, 74,01 \% орындалған, 16,86 \% орындалу сатысында тұрған. Бір көзден сатып алу бойынша да бұзылған келісім шарттар үлесі (7,23 \%) салыстырмалы түрде жоғары болған. 
Кесте 3 - 2019 жылы мемлекеттік қажеттілік үшін тауарларды жеткізу, жұмыс орындау, қызмет көрсету бойынша жасалған келісім шарттарды талдау, \%

\begin{tabular}{|c|c|c|c|c|c|c|}
\hline $\begin{array}{c}\text { Келісім } \\
\text { шарттың орын- } \\
\text { далу дәрежесі }\end{array}$ & $\begin{array}{c}\text { Баға ұсыныстарын } \\
\text { сұрату }\end{array}$ & $\begin{array}{c}\text { Ашық } \\
\text { аукцион }\end{array}$ & $\begin{array}{c}\text { Ашық } \\
\text { конкурс }\end{array}$ & $\begin{array}{c}\text { Бір көзден тау- } \\
\text { арларды сатып } \\
\text { алу }\end{array}$ & $\begin{array}{c}\text { Электрондық } \\
\text { формадағы ашық } \\
\text { аукцион }\end{array}$ & $\begin{array}{c}\text { Тауар } \\
\text { биржасындағы } \\
\text { сауда }\end{array}$ \\
\hline Бұзылды & 3,63 & 4,32 & 4,72 & 7,23 & 5,37 & 9,12 \\
\hline Орындалды & 71,33 & 57,15 & 62,23 & 51,85 & 57,36 & 74,01 \\
\hline $\begin{array}{c}\text { Орындалу бары- } \\
\text { сында }\end{array}$ & 25,02 & 38,54 & 33,05 & 40,91 & 37,26 & 16,86 \\
\hline
\end{tabular}

Сонымен 2019 жылы мемлекеттік тапсырыс бойынша орындалған келісім шарттардың орташа көрсеткіші 62,93 \% құрағанымен мемлекеттік қажеттіліктер үшін тауарларды жеткізу, жұмыс орындау, қызмет көрсету бойынша орындалмаған келісім шарттар да болғанын атап өту қажет.

\section{қОРЫТЫНДЫ}

Қазіргі интеграциялық үдерістер жағдайында Еуразиялық экономикалық кеңістік (ЕЭК) шеңберінде жаңа нарықтарды игеру, отандық жеткізушілердің бәсекеге қабілеттілігін жоғарылату, жемқорлық көріністердің орын алуын төмендету мақсатында мемлекеттік сатып алу аясындағы нормативтік-құқықтық базаны жетілдіру бойынша жүйелі түрде жұмыстар жүргізіліп, бейіндік заңға сәйкес өзгерістер мен толықтырулар енгізіліп келеді. Алайда, осыған қарамастан жемқорлық қылмыстардың орын алып жатқандығы жасырын емес. Сондықтан мұның нақты себептерін анықтап, шешу жолдарын ұсынуға, заңнамалық негіздерін жетілдіруге, «әлсіз» тұстардың болуына жол бермеу қажет.

Біздің ойымызша мемлекеттік сатып алу жүйесінің жетілмеуі бюджеттік қаражаттарды пайдалану тиімділігінің және мемлекеттік басқару механизмінің нәтижелілігінің төмен болуының басты себебі болып табылады.

Мемлекеттік сатып алудың тиімділігін жоғарылату тәсілдерінің бірі ретінде ішінара жеткізуді ұсынуға болады. Тендерлік құжаттаманы жасау кезінде ішінара жекізудің барлық ерекшеліктерін ескеру маңызды. Сондықтан мынадай шарттар мен талаптар белгіленеді:

1. Белгілі бір кезең (бір, екі, үш жыл) ішінде жеткізушінің сату көлемі оның тендерлік өтінімінің бағасының N пайызынан кем болмауы керек.

2. Тендерлік өтінімді қамтамасыз ету бойынша:

a) тендерлік өтінімді қамтамасыз ету соммасы оның бағасының пайызы түрінде берілуі керек.

б) қамтамасыз ету түрлері: банктік кепілдік және ақшалай кепіл (мұны қолдану шағын жеткізушілерге тендерлік өтінімді дайындауды оңайлатады);

в) жеткізуші міндеттемені орындамаған немесе бұзған кезде қамтамасыз ету соммасын ұстап қалу және есептеу тәртібі анық көрсетілуі тиіс.

3. Өнімнің ең төменгі партиясының мөлшері (пайыздық немесе ақшалай көріністе) айтарлықтай жоғары болғаны дұрыс. Өйткені әлеуетті жеткізушілерді қызықтыра алатындай және тапсырыс берушінің есептесуге қолайлылығын қамтамасыз етуі тиіс.

4. Тапсырыс берушінің келісім шартты бекіту кезінде жеткізу шартын өзгерту құқығының болуы.

5. Жеткізуші ұсынылғанмен салыстырғанда жеткізу көлемін ұлғайту немесе азайту шегін көрсету құқығының болуы.

Мемлекеттік сатып алу жүйесіне ішінара жеткізу әдісін тиімді түрде енгізу үшін келесілерге көңіл бөлу қажет:

- мемлекеттік сатып алу аясында білікті мамандарды дайындайтын білім беру бағдарламасын әзірлеу;

- тендерлік құжаттаманың типтік формаларын әзірлеу;

- дауларды сотқа дейін шешудің тиімді әдістерін дайындау; 
- жеткізушілердің тендерлік ұсыныстарын қабылдау мен өңдеу процесін оңтайландыру үшін бағдарламамлық қамтамасыз ету;

- ұсыныстарды бағалау, жеңімпаздарды таңдау және олардың арасында жеткізу көлемін бөлудің тиімді әдістерін әзірлеу [15].

Елімізде мемлекеттік сатып алу жүйесінің маңыздылығын ескере отырып осы сферадағы өзекті мәселелердің оң шешімін табуды қамтамасыз ету, бюджет қаражаттарының жұмсалу тиімділігін қадағалау, жемқорлық көріністердің орын алуына жол бермеу мақсатында мемлекеттік сатып алумен айналысатын арнайы агенттік құру ұсынылады. Ол елімізде өткізілетін барлық тендерлерді үйлестіру, жеткізушілердің алдын ала біліктіліктерін бағалау, қатысушылар арасында ақпарат алмасу, адекватты техникалық экспертизаны қамтамасыз ету, сапаны бақылау және басқа да маңызды мәселелермен айналысады.

Тапсырыс беруші және орындаушы тарапынан теріс пайдаланудың алдын алу және жемқорлықты болдырмау үшін мынадай іс-шаралар іске асырылуы тиіс:

- мемлекеттік сатып алудың барлық тәртібі мен кезеңдерін сипаттайтын нормативтік-құқықтық актілер мен заңнамалық негіздерді жетілдіру;

- шешім қабылдауды қолдау жүйесінде пікірлерді өңдеудің арнайы ақпараттық-аналитикалық компьютерлік технологияларды қолдану;

- тендердің қорытындысын шығаруда ашықтықты қамтамасыз ету және шенеуніктердің қабылдаған шешімдерінің тиімділігін талдау бойынша іс-шаралар кешенін дайындау;

- мемлекеттік сатып алу сферасының нормативтік-құқықтық негіздері мен этикалық ережелерді білуін тексеру мақсатында орындаушы мен тапсырыс берушінің жауапты тұлғаларын тестілеуден өткізу тәртібін енгізу.

Қорыта келгенде мемлекеттік сатып алу процесінің барлық кезеңдерінде заңбұзушылыққа қарсы барлық әдістерді теңгерімді пайдалану бойынша кешенді тәсілді қолдану арқылы ғана болуы мүмкін жемқорлық деңгейін төмендетуге қол жеткізе аламыз. Сондықтан Қазақстанда Республикасында мемлекеттік сатып алу жүйесін жетілдіру мынадай әлеуметтік-экономикалық нәтижелерге қол жеткізуге мүмкіндік береді:

- жемқорлықпен күрестің нәтижелілігін жоғарылату және мемлекеттік органдарда едәуір төмендету;

- бәсекенің дамуы және монополияға жол бермеу;

- мемлекеттік билік органдарының жүйесін жетілдіру;

- бюджеттік қаражаттардың мақсатты және тиімді пайдаланылуын қамтамасыз ету;

- бизнес субъектілерінің даму қарқынын ұлғайту;

- жаңа жұмыс орындарының ашылуы мен жұмыссыздықты азайту;

- экономикалық және әлеуметтік инфрақұрылымды дамыту т.б.

\section{ӘДЕБИЕТТЕР ТІЗІМІ}

1. Махмутова М. Государственные закупки: законодательная основа и экономические механизмы реализации. - Алматы, 2019. - $356 \mathrm{c.}$

2. Гаджиев Ф. А. Программное обеспечение конкурсных закупок ТРУ для государственных нужд // Вестник Казахского университета экономики, финансов и международной торговли. - 2018. - №1. C. $7-13$

3. Ниязов А. А. Повышение эффективности системы конкурсных закупок: монография. Караганда, 2018. - 243 с.

4. Жунусова Э. Д. Эффективность размещения государственных заказов: аналитика // Материалы III международной научно-практической конференции экономического факультета ТарГУ им. М.Х.Дулати. - Тараз, 2020. - С. 127-132.

5. Қазақстан Республикасының Мемлекеттік сатып алу туралы заңы [Электронды ресурс] // Әділет [web-портал]. - 2015. - URL: http://adilet.zan.kz/kaz/docs/Z1500000434 (қарау уақыты: 15.05.2021). 
6. Guijarro L. ICT standardisation and public procurement in the United States and in the European Union: Influence on eGovernment deployment // Telecommunications Policy. - Issues 5-6. - 2010. - P. 285-295.

7. White E. M., Carver A. D. Modeling timber mill procurement influence effects on interstate sawlog exportation // Forest Policy and Economics. - Vol. 6. - Issue 6. - 2014. - P. 529-537.

8. Rolfstam M. Optimal crude oil procurement under fluctuating price in an oil refinery // European Journal of Operational Research. - Vol. 245. - Issue 2, 1. - 2015. - P. 438-445.

9. Castro L. I., Frutos M-A. How to translate results from auctions to procurements // Economics Letters. - Vol. 106. - Issue 2. - 2010. - P. 115-128.

10. Arve M. Procurement and predation: Dynamic sourcing from financially constrained suppliers // Journal of Public Economics. - Vol. 120. - 2014. - P. 157-168.

11. Количество посетителей портала [Электронды ресурс] // Государственные закупки Республики Казахстан [web-портал]. - URL: www.goszakup.gov.kz (қарау уақыты: 15.05.2021).

12. Аналитическая отчетность АО «Банк развития Казахстана» [Электронды ресурс] // АО «Банк Развития Казахстана» [web-сайт]. - URL: www.kdb.kz (қарау уақыты: 15.05.2021).

13. Naoum Sh., Egbu Ch. Critical Review of Procurement Method Research in Construction Journals // Procedia Economics and Finance. - Vol. 21. - 2015. - P. 6-17.

14. Нурумов А. Государственный заказ как инструмент регулирования предпринимательской деятельности // Вестник КазНУ имени Аль-Фараби. - 2019. - № 4. - С. 214-219.

15. Li Zh., Ryan J. K., Sun D. Multi-attribute procurement contracts // International Journal of Innovation Economics. - Vol. 159. - 2015. - P. 137-146.

\section{REFERENCES}

1. Makhmutova, M. (2019). Gosudarstvennyye zakupki: zakonodatelnaya osnova i ekonomicheskiye mekhanizmy realizatsii, Almaty, 356 p. (In Russian).

2. Gadzhiyev, F. A. (2018), Programmnoye obespecheniye konkursnykh zakupok TRU dlya gosudarstvennykh nuzhd. Bulletin of the Kazakh University of Economics, Finance and International Trade, 1, 7-13 (In Russian).

3. Niyazov, A. A. (2018). Povysheniye effektivnosti sistemy konkursnykh zakupok: monografiya, Karaganda, 243 p. (In Russian).

4. Zhunusova, E. D. (2020). Effektivnost razmeshcheniya gosudarstvennykh zakazov: analitika. Materials of the III International Scientific and Practical Conference of the Faculty of Economics M. H. Dulati, 127-132 (In Russian).

5. Qazaqstan Respublikasynyn memlekettik satyp alu turaly zany (2015), Adilet. Retrieved May 15, 2021, from http://adilet.zan.kz/eng/docs/Z1500000434 (In Kazakh).

6. Guijarro, L. (2010). ICT standardisation and public procurement in the United States and in the European Union: Influence on eGovernment deployment. Telecommunications Policy, 5-6, 285-295

7. White, E. M. and Carver, A. D. (2014). Modeling timber mill procurement influence effects on interstate sawlog exportation. Forest Policy and Economics, 6(6), 529-537.

8. Rolfstam, M. (2015). Optimal crude oil procurement under fluctuating price in an oil refinery. European Journal of Operational Research, 245(2. 1), 438-445.

9. Castro, L. I. and Frutos, M-A. (2010). How to translate results from auctions to procurements. Economics Letters, 106(2), 115-128.

10. Arve, M. (2014). Procurement and predation: Dynamic sourcing from financially constrained suppliers. Journal of Public Economics, 120, 157-168.

11. The number of visitors to the Public Procurement portal of the Republic of Kazakhstan (n.d.). Public procurement portal of the Republic of Kazakhstan. Retrieved May 15, 2021, from www.goszakup.gov.kz

12. Analytical report (n.d.). Development Bank of Kazakhstan JSC, Retrieved May 15, 2021, from www. kdb.kz 
13. Naoum, Sh. and Egbu, Ch. (2015). Critical Review of Procurement Method Research in Construction Journals. Procedia Economics and Finance, 21, 6-17.

14. Nurumov, A. (2019). Gosudarstvennyy zakaz kak instrument regulirovaniya predprinimatelskoy deyatelnosti. Bulletin of Al-Farabi KazNU, 4, 214-219 (In Russian).

15. Li, Zh., Ryan, J. K. and Sun, D. (2015). Multi-attribute procurement contracts. International Journal of Innovation Economics, 159, 137-146.

\title{
WAYS TO IMPROVE THE EFFICIENCY OF THE PUBLIC PROCUREMENT MARKET OF THE REPUBLIC OF KAZAKHSTAN
}

\author{
R. K. Yelshibayev ${ }^{*}$, S. A. Kozhabaeva ${ }^{2}$, B. T. Beisengaliyev² \\ ${ }^{1}$ Narxoz University, Almaty, Republic of Kazakhstan \\ ${ }^{2}$ Kazakh University of Economics, Finance and International Trade, \\ Nur-Sultan, Republic of Kazakhstan
}

\begin{abstract}
Purpose of research. Development of theoretical and methodological provisions and economically sound proposals to improve the efficiency of the public procurement system of the Republic of Kazakhstan.

Methodology. In the course of the study, various methods of general scientific knowledge, comparative analysis, economic and statistical analysis were used.

Originality / value of research. The results of the study can be used in the development of regional target programs for socio-economic development, amendments and additions to the legislative and regulatory acts regulating the processes of state procurement.

Research results. Through the application of appropriate research methods, the conceptual foundations of the public procurement market are disclosed, the evolution of the public procurement system of the Republic of Kazakhstan is tracked, a comparative analysis of Kazakhstani and foreign experience in building this system is carried out, the main problems of the public procurement market functioning are identified and theoretical and methodological provisions and economically sound proposals are developed. to improve its efficiency.

Keywords: public procurement, procurement activities, tender, competitive bids, auction, state customer, potential supplier.
\end{abstract}

\section{ПУТИ ПОВЫШЕНИЯ ЭФФЕКТИВНОСТИ РЫНКА ГОСУДАРСТВЕННЫХ ЗАКУПОК РЕСПУБЛИКИ КАЗАХСТАН}

\author{
Р. К. Елшибаев ${ }^{1 *}$, С. А. Кожабаева ${ }^{2}$, Б. Т. Бейсенгалиев ${ }^{2}$ \\ ${ }^{1}$ Университет Нархоз, Алматы, Республика Казахстан \\ ${ }^{2}$ Казахский Университет экономики, финансов и международной торговли, \\ Нур-Султан, Республика Казахстан
}

\begin{abstract}
АННОТАЦИЯ
Цель исследования. Разработка теоретико-методических положений и экономически обоснованных предложений по повышению эффективности системы госзакупок Республики Казахстан.

Методология. В ходе проведения исследования применялись различные методы общенаучного познания, сравнительный анализ, экономико-статистический анализ.


Оригинальность / иенность исследования. Результаты проведенного исследования могут быть использованы при разработке региональных целевых программ социально-экономического развития, внесении изменений и дополнений в законодательные и нормативные акты, регулирующие процессы государственной закупочной деятельности.

Результаты исследования. Посредством применения соответствующих методов проведения исследования, раскрыты концептуальные основы рынка государственных закупок, отслежена эволюция системы государственных закупок Республики Казахстан, проведен сравнительный анализ казахстанского и зарубежного опыта в построении данной системы, выявлены основные проблемы функционирования рынка госзакупок и разработаны теоретико-методические положения и экономический обоснованные предложения по повышению его эффективности.

Ключевые слова: государственные закупки, закупочная деятельность, тендер, конкурсные заявки, аукцион, государственный заказчик, потенциальный поставщик.

\title{
АВТОРЛАР ТУРАЛЫ
}

Елшібаев Рақымжан Қамытбекұлы - экономика ғылымдарының кандидаты, қауымдастырылған профессор, Нархоз Университеті, Алматы, Қазақстан Республикасы, e-mail: rakymzhan.yelshibayev@, bk.ru*

Кожабаева Сауле Аманкельдиевна - экономика ғылымдарының кандидаты, доцент, Қазақ экономика, қаржы және халықаралық сауда университеті, Нұр-Сұлтан, Қазақстан Республикасы, e-mail: saule_285@mail.ru

Бейсенгалиев Берик Турсынович - экономика ғылымдарының докторы, профессор, Қазақ экономика, қаржы және халықаралық сауда университеті, Нұр-Сұлтан, Қазақстан Республикасы

МРНТИ: 14.15.01; 14.01.75

JEL Classification: I21

https://doi.org/10.52821/2224-5561-2021-3-89-109

\section{ИНКЛЮЗИВНОЕ ОБРАЗОВАНИЕ В КАЗАХСТАНЕ: АНАЛИЗ ПРОЦЕССА ОРГАНИЗАЦИИ И ВОЗМОЖНОСТИ ДАЛЬНЕЙШЕГО ЕГО РАЗВИТИЯ}

\author{
М. Б. Турлубекова ${ }^{1 *}$, Р. О. Бугубаева ${ }^{1}$ \\ ${ }^{1}$ Карагандинский Экономический Университет Казпотребсоюза, \\ Караганда, Республика Казахстан
}

\begin{abstract}
АННОТАЦИЯ
Целью исследования является анализ процесса организации и возможности использования инклюзивного образования в Казахстане на основе выявленных прогнозных значений.

Методологической основой исследования является система различных приемов, которые составляют комплекс методов, механизмов, принципов, мероприятий по повышению эффективности использования инструментов совершенствования инклюзивного образования.

Методы исследования. В рамках проведенного исследования применялись:

- теоретические, включающие анализ отечественных и зарубежных ученых в области инклюзивного образования;

- анализ законодательных и нормативных документов;

- методы математического моделирования и прогнозирования.

- метод графического представления полученных результатов.
\end{abstract}

